\title{
Santonian ammonites from the Köpingsberg-1 borehole, Sweden
}

\author{
WILLIAM JAMES KENNEDY AND WALTER KEGEL CHRISTENSEN
}

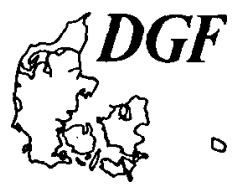

\begin{abstract}
Kennedy, W.J. \& Christensen, W.K.: Santonian ammonites from the Köpingsberg-1 borehole, Sweden. Bull. geol. Soc. Denmark, vol. 40, pp. 149-156, Copenhagen, June 3th, 1993. https://doi.org/10.37570/bgsd-1993-40-05

A 510 meter succession of siltstones and fine sandstones in the Köpingsberg-1 borehole, Sweden yielded a distinctive suite of Santonian ammonites; ammonites of this age are otherwise known in significant numbers in Scandinavia only on Bornholm. The assemblage is dominated by taxa best known from North Germany, and includes Hauericeras cf. pseudogardeni (Schlüter, 1872), Scalarites sp., Baculites sp. group of capensis Woods, 1906, Baculites sp. 1, Boehmoceras krekeleri (Wegner, 1905), Boehmoceras arculus (Morton, 1834), and Scaphites kieslingswaldensis fischeri Riedel, 1931.
\end{abstract}

W.J. Kennedy, Geological Collections, University Museum, Oxford OX1 3PW, England. W.K. Christen-sen, Geological Museum, Øster Voldgade 5-7, DK-1350 Copenhagen, Denmark. 3 June 1991.

\section{Introduction}

A series of cores from the Köpingsberg-1 borehole, Sweden (Fig. 1), cut in grey, sometimes glauconitic micaceous siltstones and sandstones yielded a small suite of ammonites of Santonian age. In view of the paucity of ammonite assemblages of this age in Scandinavia, where they are otherwise known mainly from Bornholm: (Kennedy \& Christensen, 1991), the present material, though limited, merits description. The borehole was drilled in 1967 and described or commented upon by Anderegg, Norling \& Skoglund (1968), Norling (written comm. January 121970 ) and Chatziemmannouil (1982). It is situated in the southeastern part of the Vomb Trough in Scania, Sweden about $9 \mathrm{~km}$ eastnortheast of Ystad (Fig. 1). The trough is a narrow, elongated, asymmetrical graben initiated in the Early Mesozoic (Norling 1982, Chatziemmanouil 1982). The length of the trough is about $80 \mathrm{~km}$ and its width is about $7 \mathrm{~km}$ towards the northwest and $11 \mathrm{~km}$ towards the southeast. The Herrestad Uplift, an east-west trending horst in the southeastern part of the trough, divides the trough into two parts.

About $1000 \mathrm{~m}$ of Cretaceous rocks, consisting mainly of glauconitic, calcareous, clayey siltstones spanning the Hauterivian-Maastrichtian, were recorded from the borehole. The thickness of the Upper Cretaceous sedimentary strata is a little less than $800 \mathrm{~m}$, and all Upper Cretaceous stages are represented. The stratigraphical dating of the borehole was made mainly on the basis of foraminifera (Norling op. cit., Chatziemmanouil 1982). On the basis of these studies the borehole was subdivided in the following way: Pleistocene 0-20 m, Lower Maastrichtian 20-71 m, Campanian 71-230 m, Santonian 230-600 m, Coniacian 600-670 m, Turonian 670-742 m, and Cenomanian 742-805 m.

Christensen (1986) described the Upper Cretaceous belemnites from five classic outcrops and one borehole in the through, and these were placed in the international stratigraphic framework on belemnite evidence.

Chatziemmanouil (1982) analysed the Upper Cretaceous of the trough on the basis of five boreholes, including Köpingsberg-1, placed along the axis of the trough. The analysis was based upon seismic methods, sedimentological analysis, and palaeontological/ecological studies of foraminifera.

The fossils are all crushed and fragmentary composite moulds, a few with traces of powdery phosphatized shell. The assemblage is dominated by Baculites, mostly indeterminate, which range from depths of 132.35-132.44 $\mathrm{m}$ down to 642.62$642.69 \mathrm{~m}$.

Detailed records are as follows: 132.35-132.44 m Baculites sp.? 251.70-251.75 m Baculites sp. group of capensis 314.80-314.86 m Baculites sp.?

315.18-315.23 m Baculites sp.? 
316.78-316.8 m Baculites sp. 1

338.70-338.74 m Baculites sp. 1

339.71-339.77 m Baculites sp. 1

341.68-341.71 m Baculites sp. 1

$397 \mathrm{~m}$

Scaphites kieslingswaldensis

fischeri

433.84-433.86 m Hauericeras cf. pseudogardeni 481.26-481.35 m Boehmoceras arculus

491.91-491.96 m Baculites sp. group of capensis 494.13-494.18 m Baculites sp.

$511.25-511.33 \mathrm{~m}$ indeterminate juvenile ammonite

524.74-524.78 m Boehmoceras sp. juv. cf. krekeleri

524.87-525.03 m Boehmoceras krekeleri, Baculites $\mathrm{sp}$. group of capensis, Scalarites? sp.

525.18-525.29 m Boehmoceras krekeleri

526.08-526.17 m Boehmoceras krekeleri

526.58-526.66 m Boehmoceras krekeleri

527.12-527.23 m Boehmoceras krekeleri

530.11-530.13 m Boehmoceras krekeleri

532.11-532.16 m Baculites sp. 1

559.77-559.80 m Baculites sp. 1

561.13-561.16 m Scaphites cf. kieslingswaldensis fischeri

572.46-577.58 m Baculites sp. 1

581.92-581.97 m Baculites sp. 1

588.92-588.97 m Baculites sp. 1

604.60-604.66 m Baculites sp.?

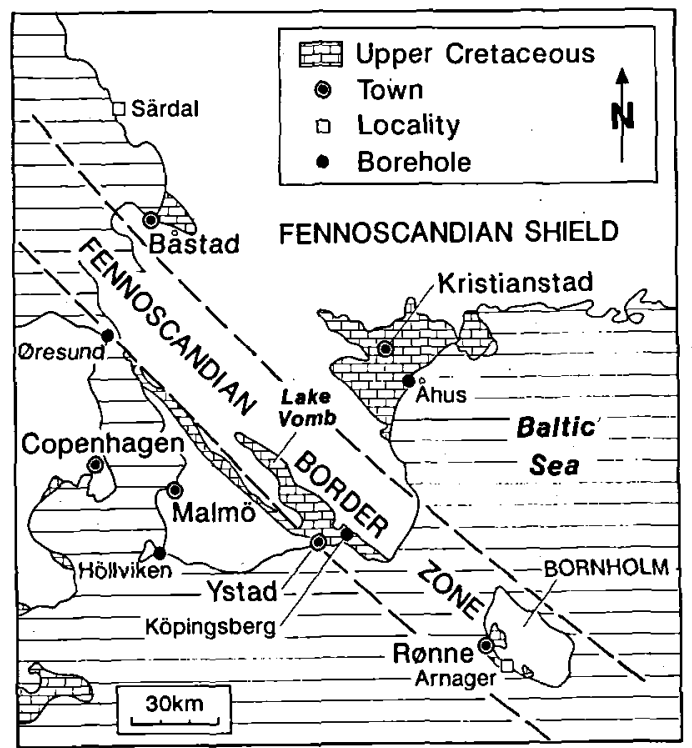

Fig. 1. The location of the Köpingsberg-1 borehole in the Vomb Trough (modified after Christensen 1985).
611.75-611.76 m Baculites sp.?

624.87-624.95 m Scaphites kieslingswaldensis fischeri

642.62-642.69 m Baculites sp. 1

\section{Age of the Assemblage}

The interval between 132.35 and $481.26 \mathrm{~m}$ cannot be dated precisely. The nodose Baculites present are of the $B$. capensis (Woods, 1906) group, which range from Upper Coniacian to Upper Santonian (Klinger \& Kennedy, 1977), suggesting, given the Upper Santonian age of the underlying sediments, that these too are Upper Santonian. The presence of Scaphites (Scaphites) kieslingswaldensis fischeri Riedel, 1931, at $397 \mathrm{~m}$ is compatible with such an age; this species ranges from Lower Santonian to Lower Campanian in Germany (see discussion in Kennedy \& Christensen, 1991).

The presence of Boehmoceras arculus (Morton, 1834) at 481.26-481.35 m, and Boehmoceras krekeleri (Wegner, 1905) between 527.74 and $530.13 \mathrm{~m}$ provide a precise dating, for Schönfeld (1985) has refined previous records, showing the species to occur in association with the pelagic crinoid Marsupites in the Marsupites/granulata Zone in the Münster Basin. This same zone yields Hauericeras pseudogadeni (Schlüter, 1872), a possible example of which is present at 433.84-433.86 m. Poorly preserved Scaphites (Scaphites) kieslingswaldensis fischeri at $624.87-$ $624.95 \mathrm{~m}$ suggest that the interval to this depth is also Santonian, although foraminiferal data (Chatziemmanouli 1982) placed the ConiacianSantonian boundary at a depth of $600 \mathrm{~m}$. This may simply reflect differing definitions of the boundary.

Systematic Palaeontology

Order Ammonoidea Zittel, 1884

Suborder Ammonitina Hyatt, 1889

Superfamily Desmocerataceae Zittel, 1895

Family Desmoceratinae Zittel, 1895

Subfamily Hauericeratinae Matsumoto, 1938

Genus Hauericeras de Grossouvre, 1984

[= Schlueteria Rollier, 1922, p.359, non Fritsch in

Fritsch \& Kafka, 1887, p.33; Pseudogarneria Tomlin, 1930, p.23; Gardeniceras Matsumoto \& Obata, 1955, p.134] 


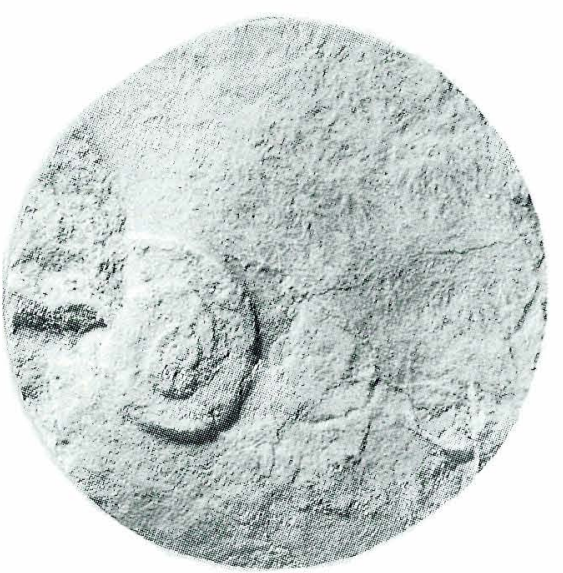

A

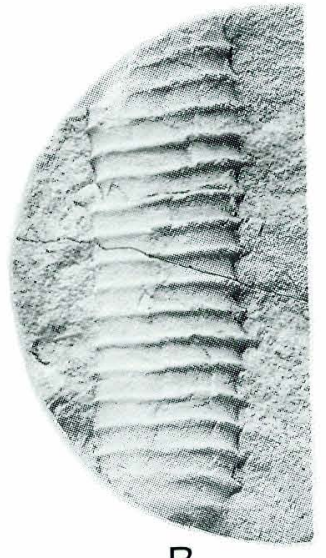

B
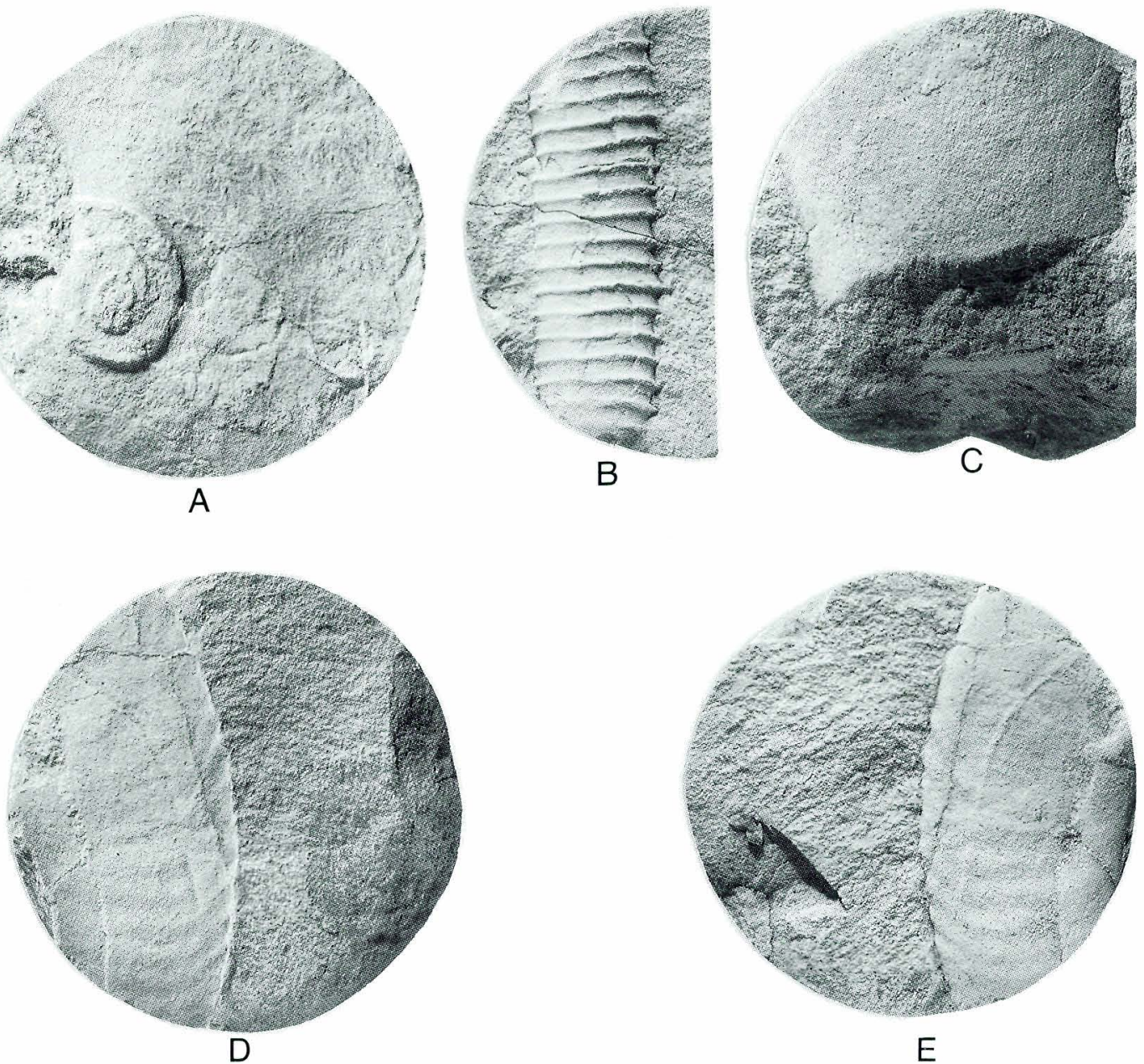

$\mathrm{E}$

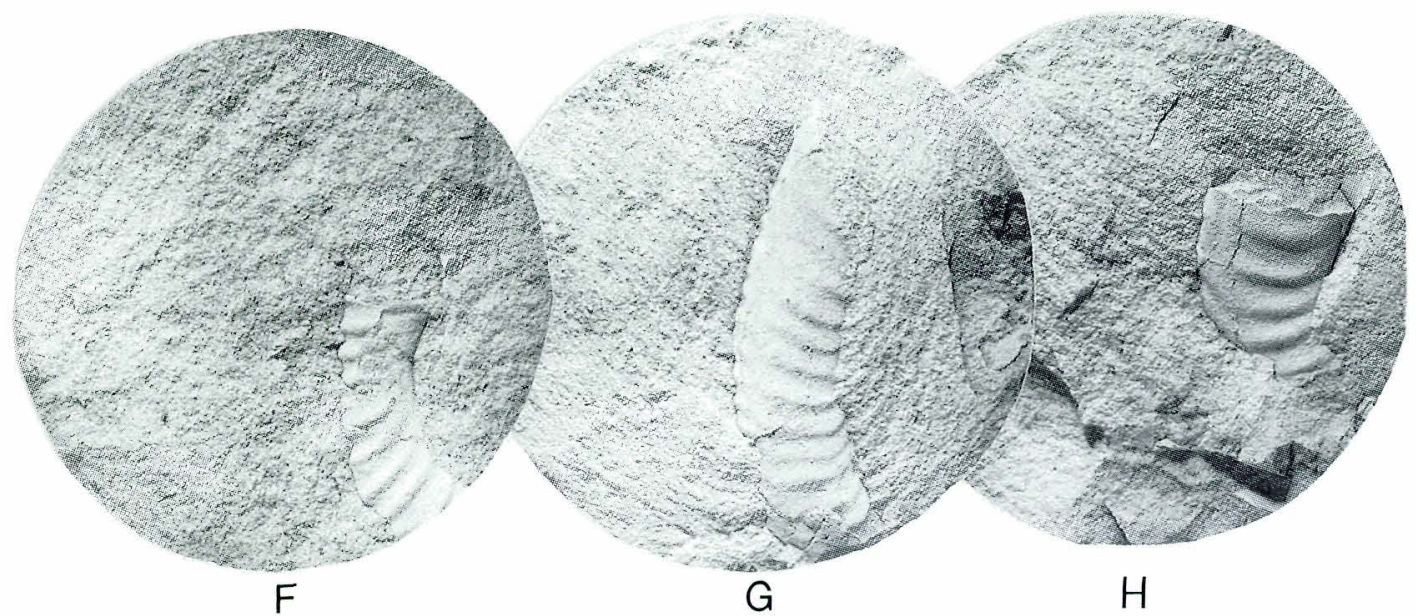

Fig. 2. A, Hauericeras cf. pseudogardeni (Schlüter, 1872) $433.84-433.86 \mathrm{~m}$. B. Scalarites sp. 524.87-525.03 m. C, Baculites sp. 1. 338.70-338.74 m. D-H, Boehmoceras krekeleri (Wegner, 1905); D, E, 526.58-526.66 mm. F, 524.87-525.03 m. G, 530.11-530.13 m. H, $526.08-526.17 \mathrm{~m}$. 
Type species: Ammonites gardeni Baily, 1855, p.450, pl.11, fig. 3 , by original designation.

Hauericeras cf. pseudogardeni (Schlüter, 1872)

Fig. 2A

compare:

1872 Ammonites pseudogardeni Schlüter, p.54, pl.16, figs. 3-6.

Description: The specimen is the composite mould of the umbilicus and part of a septate whorl, occupying the whole of the surface of the core, $55 \mathrm{~mm}$ in diameter. Coiling is very involute, the umbilicus very shallow, with a low, flattened wall and sharp umbilical shoulder. The flanks, so far as preserved, are flat, smooth, with traces of a deeply incised suture line of desmoceratacean type.

Discussion: Although rather unpromising, the Upper Santonian age of this specimen, suture, coiling, very shallow umbilicus and smooth shell surface suggest it to be a part of a Hauericeras, probably $H$. pseudogardeni. A faint radial ridge (corresponding to a groove on the surface of the internal mould) can be felt at one point on the surface, and this is a typical feature of the genus. We have been unable to trace the original of Schlüter's figure of the shell of this species (1872, pl.16, figs. 3,4 ), but the specimen upon which he
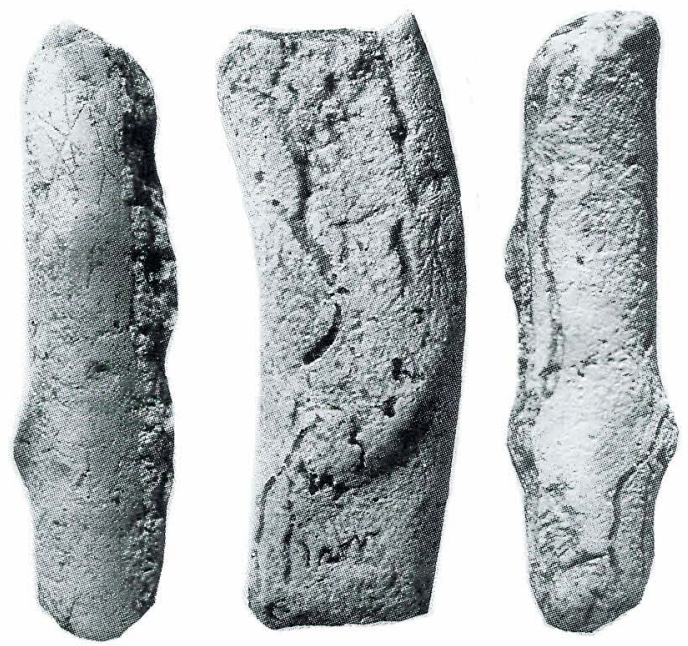

Fig. 3. The lectotype of Boehmoceras arculus (Morton, 1834), in the collections of the Academy of Natural Sciences of Philadelphia, and from the 'older Cretaceous strata of Greene County, Alabama', that is to say, the Tombigbee Sand Member of the Eutaw Formation. All figures are $\times 1$. based his illustrations of the suture (1972, pl.16, figs. 5, 6), from Dülmen, Westphalia, is in the collection of Geologisches und Paläontologisches Institut, Bonn (GAB48), and compares closely with the present fragment.

Occurrence: Köpingsberg borehole, 433.84$433.86 \mathrm{~m}$. H. pseudogardeni has been recorded from both Upper Santonian and Lower Campanian, with records from northern England, Germany, European Russia, and the Crimea. Hauericeras cf. pseudogardeni is recorded from Ignaberga and Eriksdal by Birkelund \& Bromley (1979), and from the Höllviken-2 borehole by Ødum (1953).

Suborder Ancyloceratina Wiedmann, 1966

Superfamily Turrilitaceae Gill, 1871

Family Diplomoceratidae Spath, 1926

Subfamily Diplomoceratinae Spath, 1926

Genus Scalarites Wright \& Matsumoto, 1954

Type species: Helicoceras scalare Yabe, 1904, p.9, pl.3, fig. 2, by original designation

\section{Scalarites sp.}

Fig. 2B

Description: The single specimen shows all of the flank of one side of the shell, $55 \mathrm{~mm}$ long, with a maximum preserved whorl height of $18 \mathrm{~mm}$. Ornament is of sharp, distant feebly prorsiradiate ribs that are weakened on the dorsum, but strengthen markedly on the venter, where some appear to be accentuated and flared; the rib index is 6.

Discussion: The present specimen compares closely in ribbing style with one of the specimens of Crioceras serta Müller and Wollemann, 1906 (pl.10, fig. 4), differing only in being straight rather than curved.

Occurrence: Köpingsberg borehole, 524.87$523.03 \mathrm{~m}$.

Family Baculitidae Gill, 1871

Genus Baculites Lamarck, 1799

Type species: Baculites vertebralis Lamarck, 1801, p. 80 , by subsequent designation by Meek, 1876, p.391.

Baculites sp. group of capensis Woods, 1906

Fig. 4A 

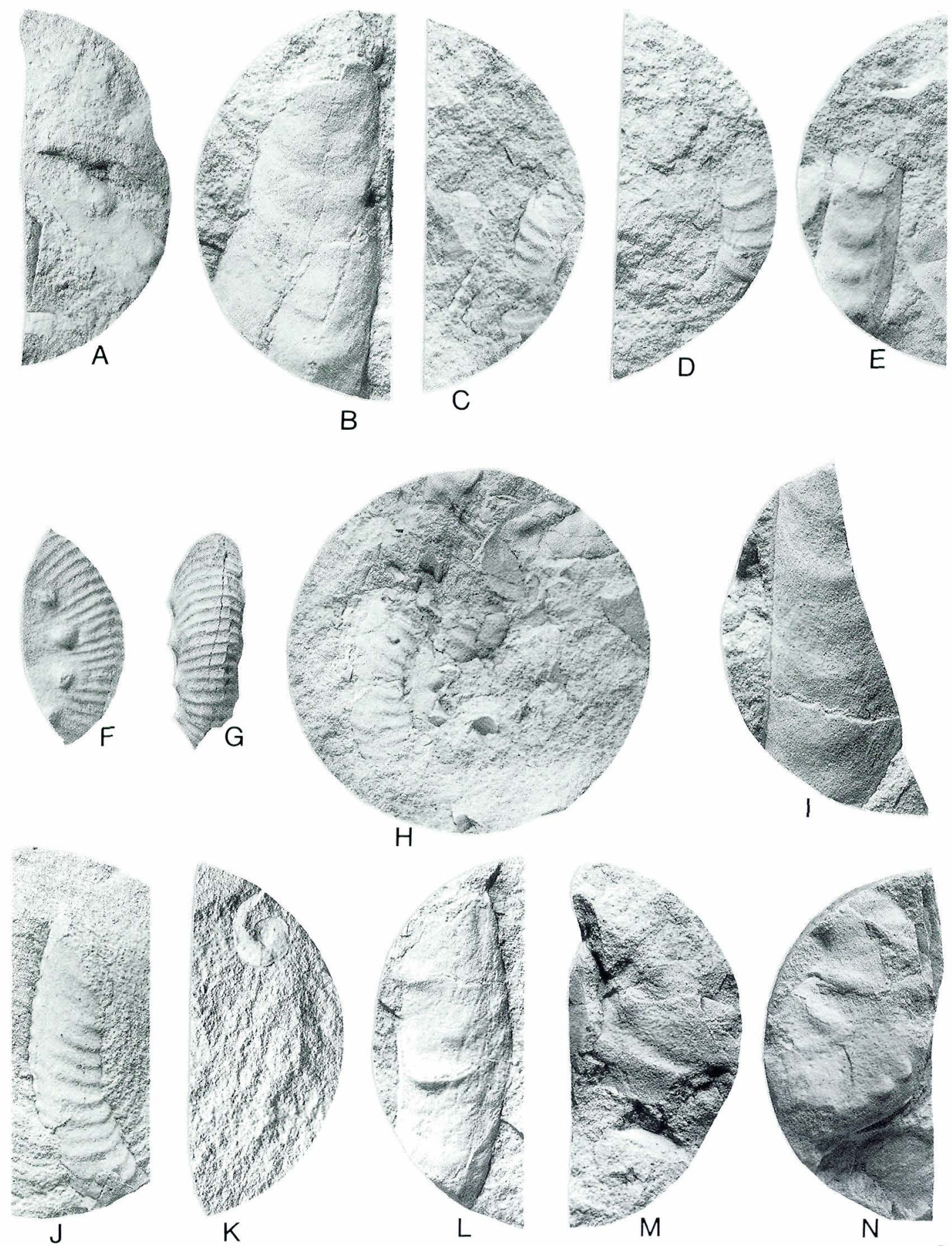

Fig. 4. A, Baculites sp., group of capensis Woods, 1906, 491.91-491.96 m. B, E, I, Baculites sp. 1; B, 341.68-341.71 m. E, 251.70-251.75 m. I, 251.70-251.75 m. C, D, H, J, Boehmoceras krekeleri (Wegner, 1905); C, 525.18-525.29 m. D, $527.12-527.23 \mathrm{~m}$. E, 251.70-251.75 m. H, 524.87-525.08 m. J, 530.11-530.13 m. F, G, M, N, Scaphites (Scaphites) kieslingswaldensis fischeri Riedel, 1931; F, G, 397 m. M, 561.13-561.16 m. N, 624.87-624.95 m. K, indeterminate juvenile ammonite. L. Boehmoceras arculus (Morton, 1834), 481.26-481.35 m. All figures are $\times 1$. 
Discussion: Although Baculites are the commonest ammonites in the Köpingsberg borehole; the material is all poorly preserved, with only limited diagnostic features. Small specimens with conical dorsolateral nodes that give rise to feeble, rapidly effacing concave ribs on the middle and ventral parts of the flank most closely resemble the widely occurring Upper Coniacian to Lower Santonian Baculites capensis group (see discussion in Klinger \& Kennedy, 1977, and Kennedy \& Cobban, 1991).

Occurrence: Köpingsberg borehole, 251.70$251.75 \mathrm{~m}, 491.91-491.96 \mathrm{~m}, 524.87-525.03 \mathrm{~m}$.

\section{Baculites sp. 1}

Figs. 2C, 4B, E, I

Discussion: A second, larger Baculites has a whorl height of up to $42 \mathrm{~mm}$. The shell varies from smooth (Fig. 2C) to ornamented by widely separated crescentic dorsolateral ribs (Fig. 4I), and parallel growth striae (Fig. 4B).

Occurrence: This is the commonest ammonite in the Köpingsberg borehole and occurs at depths of $316.78-642.69 \mathrm{~m}$.

Genus Boehmoceras Riedel, 1931

Type species: By subsequent designation by Wright, 1957, p.L220: Ancyloceras krekeleri Wegner, 1905, p.210, pl.8, fig. 2.

Boehmoceras krekeleri (Wegner, 1905)

Figs. 2D-H, 4C, D, H, J

1905 Ancyloceras krekeleri Wegner, p.210, pl.8, fig. 2

1931 Boehmoceras krekeleri (Wegner): Riedel, p.691, pl.77, figs. 3-5; pl.78, figs. 1, 2.

1979 Boehmoceras krekeleri (Wegner); Summesberger, p.118, pl.2, fig. 14; text-figs. 7, 8 .

1983 Boehmoceras Kennedy \& Wright, p.866.

1985 Boehmoceras krekeleri (Wegner); Schönfeld, pl.2, fig. 4.

1987 Boehmoceras krekeleri (Wegner); Kennedy, p.778, text-figs. $3 a$, b.

Types: These appear to be lost. They were from the Santonian of the Münster Basin, Germany.
Discription: Specimens consist of curved shafts with whorl heights of between 8 and $27 \mathrm{~mm}$. On small specimens (e.g. Figs. 2F-H, 4C, D, J) ornament is of blunt, prorsiradiate concave ribs that are strongest on the dorsolateral flank, sweeping forwards and declining on the ventral flanks and strengthening over the venter, which is markedly crenulate in profile; the rib index is 4 . In the largest specimen (Fig. 2D, E) the style of ornament is similar, but the ribs weaken and are much more crowded, with a rib index of 6 and occasional shorter intercalated ribs.

Discussion: The very even ribbing shows these specimens to be Boehmoceras krekeleri; B. arculus (Morton, 1834) (= B.loescheri Riedel, 1931, p.692, pl.78, figs. 3-6; see revision in Kennedy \& Cobban, 1991, p.82, figs. 6:2, 8; 8:9-15, 18-22; $9: 1,2,11-52 ; 10: 20,21,24-26 ; 12: 3$, and Figs. 3 and $4 \mathrm{~L}$ herein) differs in having coarse, distant crescentic dorsolateral bullae giving rise to one or more ribs, with the wide interspaces ornamented by numerous weaker intercalated minor ribs that strengthen markedly on the venter.

Occurrence: Upper Santonian, Recklinghäuser Mergel, Marsupites/granulata Zone of the Münster Basin, Germany. Upper Santonian 'sandsteinbank' of the Gosau Basin. In the Köpingsberg borehole, we have specimens from 524.74 $524.78 \mathrm{~m}, 524.87-525.03 \mathrm{~m}, 525.18-525.29 \mathrm{~m}$, 526.08-526.17 m, 526.58-526.66 m, 527.12$527.23 \mathrm{~m}$, and $530.11-530.13 \mathrm{~m}$.

Boehmoceras arculus (Morton, 1834)

Figs. 3, 4L

1834 Hamites arculus Morton, p.44, pl.15, figs. 1. 2.

1834 Hamites arculus var. A, Morton, p.45.

1937 Boehmoceras löscheri Riedel, p.692, pl.78, figs. 3-6.

1971 Boehmoceras löscheri Riedel; Ulbrich, pl.5, fig. 4 .

1979 Boehmoceras loescheri Riedel; Summesberger, p.119, pl.2, figs. $15,16,18$; textfigs. 9-12.

1983 Boehmoceras Kennedy \& Wright, p.866.

1985 Boehmoceras sp., Kennedy, pl.2, fig. 1.

1985 Boehmoceras loescheri Riedel; Schönfeld, pl.2, fig. 6. 
1987 Boehmoceras loescheri Riedel; Kennedy, p.777, pl.82, figs. 4-16; text-fig. 2.

1991 Boehmoceras arculus (Morton); Kennedy \& Cobban, p. 182, figs. $6: 2,8 ; 8: 9-15$. $18-22 ; 9: 1,2,11-52 ; 10: 20,21,24-26 ; 12: 3$.

Types: Morton illustrated two specimens, and Richards (1968) refers to 2-5 cotypes (one missing) in the collections of the Academy of Natural Sciences of Philadelphia, and from the "older Cretaceous strata of Greene County, Alabama", that is to say the Tombigbee Sand Member of the Eutaw Formation. We here designate the cotype shown in Fig. 3 lectotype of the species.

Description: The specimen consist of a curved fragment $48 \mathrm{~mm}$ long, with a maximum preseved whorl height of $18 \mathrm{~mm}$. Ornament consists of strong, concave, narrow, crescentic, distant dorsolateral bullae that give rise to a narrow rib that effaces across the ventral part of the flanks. The interspaces bear numerous minor ribs that are best developed on the venter, giving it a feebly crenulate appearance when viewed in profile.

Discussion: The present specimen differs in no significant respects from the lectotype (Fig. 3), and falls well within the range of variation documented by Kennedy \& Cobban (1991). The very distant umbilicolateral bullae and numerous minor ribs between immediately distinguish it from the evenly ribbed Boehmoceras krekeleri, described above.

Occurence: Upper Santonian Texanites shiloensis Zone in Mississippi, Alabama, and the Big Bend area of Texas in the USA, Upper Santonian Recklingshauser Mergel, Marsupites/granulata Zone of the Münster Basin, Germany (Schönfeld, 1985), but said to be longer-ranging in the Subhercynian Cretaceous Basin (Ulbrich, 1971). Assizes $\mathrm{M}^{2}$ and $\mathrm{N}^{2}$ in the Aquitaine Basin. Upper Santonian 'Sandsteinbank' of the Gosau Basin. In the Köpingsberg borehole we have a single specimen from $481.26-481.35 \mathrm{~m}$.

Superfamily Scaphitaceae Gill, 1871

Family Scaphitidae Gill, 1871

Subfamily Scaphitinae Gill, 1871

Genus and Subgenus Scaphites Parkinson, 1811

Type species: Scaphites equalis J. Sowerby, 1813, p.53, pl.18, figs. $1-3$; by subsequent designation by Meek $(1876$, p.413).

Scaphites (Scaphites) kieslingswaldensis fischeri Riedel, 1931

Figs. 4F, G, M, N

1931 Scaphites fischeri Riedel, p.704, pl.79, figs. $5,6$.

1991 Scaphites fischeri Riedel: Kennedy \& Christensen, p.222, pl.2, figs. 1, 2; pl.5, fig. 2 ; pl.6, figs. $2,3,4,7 ;$ pl.7, figs. 2,4 .

Lectotype: The original of Riedel, 1931, pl.79, fig. 6, designated by Kennedy \& Christensen, 1991, p.223.

Discussion: We recently described and discussed this species at length $(1991$, p.222). The present material consists of one well-preserved fragment of the early body chamber (Figs. 4F, G) and two fragments of the late body chamber (Figs. 4M, N).

Occurrence: Lower Santonian to Lower Campanian of the Münster Basin and elsewhere in Germany. It occurs in the Köpingsberg- 1 borehole at $397 \mathrm{~m}, 561.13-561.6 \mathrm{~m}$ and $624.87-624.95 \mathrm{~m}$.

Acknowledgements. We thank Dr. S. Laufeld, formerly at the Swedish Geological Survey, Uppsala, for allowing us to study the material from the Köpingsberg-1 borehole. Kennedy acknowledges the financial support of the Natural Environment Research Council (U.K.), and technical assistance of the staff of the Geological Collections, University Museum, Oxford, and Department of Earth Sciences, Oxford, UK. Christensen acknowledges the financial support of the Carlsberg Foundation.

\section{Dansk sammendrag}

Ammonitterne fra et $510 \mathrm{~m}$ interval i Köpingsberg-1 boringen $\mathrm{i}$ Vomb truget $\mathrm{i}$ Skåne beskrives. Faunaen består af følgende taxa: Hauericeras cf. pseudogardeni, Scalarites sp., Baculites sp. group of capensis, Baculites sp. 1, Boehmoceras krekeleri, Boehmoceras arculus og Scaphites kieslingswaldensis fischeri. Denne fauna er af Santonien alder og kendes bedst fra Tyskland. I Skandinavien er Santonien ammonitter sjældne bortset fra forekomsten på Bornholm.

\section{References}

Anderegg H. J., Norling, E. \& Skoglund, R. (1968): SGU oljegeologiska arbeten 1967-1968. Sver. Geol. Unders., Rapport, 8 pp. 
Baily, W. H. (1855): Description of some Cretaceous fossils from South Africa. Q. Jl. geol. Soc. Lond. 11, 454-465, pls. 11-13.

Birkelund, T. \& Bromley, R. G. (1979): Hauericeras cf. pseudogardeni in the Upper Cretaceous of Ignaberga, Sweden. Geol. Fören. Stockholm Förh., 101, 173-176.

Chatziemmaouil, J. P. (1982): The Upper Cretaceous of the Vomb Trough southern Sweden. Part I. Structure geology and sedimentology. Part II. Foraminiferal palaeoecology of the Coniacian and Santonian sequences and its application. Stockh. Contr. Geol. 38, 57-161.

Christensen, W. K. (1986): Upper Cretaceous belemnites from the Vomb Trough in Scania. Sver. Geol. Unders. Ca 57, $57 \mathrm{pp}$.

Fritsch, A. \& Kafka, J. (1987): Die Crustaceen der böhmischen Kreideformationen. Selbstverlag, Prague, $53 \mathrm{pp}$.

Gill, T. (1871): Arrangement of the Families of Mollusks. Smithson, Misc. Collns, 227, xvi $+49 \mathrm{pp}$.

Grossouvre, A. de (1984): Recherches sur la craie supériure, 2, Paléontólogie. Les ammonites de la craie supérieure. Mém. Serv. Carte géol. dét. Fr.,. 264 p., 39 pls. (misdated 1893).

Hyatt, A. (1989): Genesis of the Arietidae. Smithson. Contrib. Knowl, $673, \mathrm{xi}+239$ pp. 14 pls.

Kennedy, W. J. (1985): Ammonite faunas of the Coniacian, Santonian and Campanian stages in the Aquitaine Basin. Géol. Méditerranéenne, 10, 103-113.

Kennedy, W. J. (1987): Ammonites from the type Santonian and adjacent parts of northern Aquitaine (western France). Palaeontology, 30, 765-782, pls 80-82.

Kennedy, W. J. \& Christensen, W. K. (1991): Coniacian and Santonian ammonites from Bornholm. Bull. geol. Soc. Denmark, 38, 203-226.

Kennedy, W. J. \& Cobban, W. A. (1991): Upper Cretaceous (upper Santonian) Boehmoceras fauna from the Gulf Coast region of the United States. Geol. Mag., 128, 167198.

Klinger, H. C. \& Kennedy, W. J. (1877): Upper Cretaceous ammonites from a borehole near Richards Bay, South Africa. Ann. S. Afr. Mus.., 72, 69-107.

Kennedy, W. J. \& Wright, C. W. (1983): Ammonites polyopsis Dujardin, 1837 and the Cretaceous ammonite family Placenticeratidae Hyatt, 1900. Palaeontology, 26, 855-873, pls. 85-87.

Lamarck, J. P. B. A. de M. de (1799): Prodrome d'une nouvelle classification des coquilles. Mém. Soc. Hist. Nat. Paris, (1799), 63-90.

Lamarck, J. P. B. A. de M. de (1801): Système des Animaux sans vertebrès. The author; Deterville, Paris, vii $+432 \mathrm{pp}$.

Matsumoto, T. (1938): A biostratigraphic study on the Cretaceous deposits of the Naibuchi Valley, South Karahuto. Proc. Imp. Acad. 14, 190-194.

Matsumoto, T. \& Obata, I. (1955): Some Upper Cretaceous Desmoceratids from Hokkaido and Saghalien. Mem. Fac. Sci. Kyushu Univ., Series D, Geology, 5, 119-151, pls. 24-30.

Meek, F. B. (1876): A report on the invertebrate Cretaceous and Tertiary fossils of the upper Missouri country. In Hayden, F. V. Report of the United States Geological Survey of the Territories, 9, 1xiv +629 pp., 45 pls.

Morton, S. G. (1834): Synopsis of the organic remains of the Cretaceous groups of the United States. Illustrated by nineteen plates, to which is added an appendix containing a tabular view of the Tertiary fossils discovered in America. Key and Biddle, Philadelphia, 88 pp., 18 pls.
Müller, G. \& Wollemann, A. (1906): Die Molluskenfauna des Untersenon von Braunschweig und Ilsede. II. Die Cephalopoden. Abh. preuss. geol. Landesanst., 47, 1-30, pls. $1-11$.

Norling, E. (1982): Eriksdal (and adjacent Kullemölla valley). In Bergström, J. Holland, B., Larsson, K., Norling, E. \& Sivhed, U. (eds): Guide to excursions in Scania. Sver. Geol. Unders. Ca. 54, 75-81.

Ødum, H. (1953): De geologiska resultaten frản borningarna vid Höllviken. V. The macro-fossils of the Upper Cretaceous. Sver. Geol. Unders. C 527, 37 pp.

Parkinson, J. (1811): Organic remains of a former world, 3: J. Robson, London, 479 p.

Riedel, L. (1931): Zur Stratigraphie und Faciesbildung im Oberemscher und Untersenon im Südrande des Beckens von Münster. Jb. preuss. geol. Landesanst. 51: 605-713, pls. 72-79.

Rollier, L. (1922): Phylogenie des ammonites. Eclog. geol. Helv., 17, 358-360, pls. 20-22.

Schlüter, C. (1871-1876): Cephalopoden der oberen deutschen Kreide. Palaeontographica, 21, 1-24, pls. 1-8 (1871); 21 , 25-120, pls. 9-35 (1872); 24, 1-144 (121-264) + x. pls. $36-55$ (1876).

Schönfeld, J. (1985): Zur Lithologie, Biostratigraphic und Fossilführung des Ober-Santon Mergels von Westerwich (Östwestfalen). Geol. Paläont. Westf., 5, 7-20, 2pls.

Sowerby, J. (1812-1822): The mineral conchology of Great Britain. 1, pls. $1-9(1812)$, pls. $10-44$ (1813), pls. $45-78$ (1814), pls. 79-102 (1815); 2, pls. 103-114 (1815), pls. 115-150 (1816), pls. 151-186 (1917), pls. 187-203 (1818),3, pls. 204-221 (1818), pls. 222-253 (1819), pls. 254-271 (1820), pls. $272-306$ (1821); 4, pls. 307-318 (1821), pls. 319-383 (1822). The author, London.

Spath, L. F. (1926): On new ammonites from the English Chalk. Geol. Mag., 63, 77-83, table.

Summesberger, H. (1979): Eine obersantone Ammoniten fauna aus dem Becken von Gosau (Oberösterreich). Ann. Naturhist. Mus. Wien, 83, 275-283, 3 pls.

Tomlin, J. R. U. B. (1930): Some preoccupied generic names II. Proc. malac. Soc. Lond., 19, 22-24.

Ulbrich, H. (1971): Mitteilungen zur Biostratigraphic des Santon und Campan des mittleren Teils der Subherzynen Kreidemulde. Freib. Forsch.Hft., 267, 47-60, 5 pls.

Wegner, T. (1905): Die Granulatenkride des westlichen Münsterlandes. Z. dt. Geol. Ges., 57, 112-232, pls. 7-10.

Wiedmann, J. (1966): Stammesgeschichte und system den posttriadischen ammonoideen; ein überblick. Neues $\mathrm{Jb}$. geol. Paläont.Abh., 125, 49-79, pls. 1-2; 127, 13-81, pls. 3-6.

Woods, H. (1906): The Cretaceous fauna of Pondoland. Ann. S. Afr. Mus., 4, 275-350, pls. 33-44.

Wright, C. W. (1957): [Cretaceous Ammonoidea]. In Moore, R. C. $(e d)$. Treatise on Invertebrate Paleontology. Part L, Mollusca 4, Cephalopoda Ammonoidea. xxii + 490 pp., New York and Lawrence, Geological Society of America and University of Kansas Press.

Wright, C. W. \& Matsumoto, T. (1954): Some doubtful Cretaceous ammonite genera from Japan and Saghalien. $\mathrm{Mem}$. Fac. Sci. Kyushu Univ. (D). Geol., 4, 107-134, pls. 7-8.

Yabe, H. (1904): Cretaceous Cephalopoda from Hokkaido. Part II. J. Coll. Sci. imp. Univ. Tokyo, 20, 1-45, pls. 1-6.

Zittel, K. A. von (1884): Handbuch der Palaeontology. 1, Abt. 2; Lief 3, Cephalopoda, pp. 329-522. R. Oldenbourg. Munich \& Leipzig.

Zittel, K. A. von (1895): Grundzüge der Palaeontologie (Palaeozoologie). R. Oldenbourg, Munich \& Leipzig, vii +972 pp. 